\title{
Counseling Practices in Monitoring Vocational Behaviour of Students in Tertiary Institution
}

\author{
Omeje Joachim Chinweike, Eskay Michael, \\ University of Nigeria, \\ Nsukka, Nigeria
}

\author{
Tenimu Sani \\ College of Education, \\ Ankpa, Nigeria
}

\begin{abstract}
The study investigated counseling practices in monitoring vocational behaviors of students in tertiary institution. Two research questions and two hypotheses guided the study. The subjects for the study comprise 72 female and 43 male counselors drawn from both Nsukka and Obollo Afor education zones of Enugu State. The instrument for data collection was questionnaire, mean score, and $t$-test statistics were used in data analysis. Results showed that the approaches counselors use in equipping students with vocational information for career choice are media outlet, individual counseling, group counseling, career day/week, field trip/excursion, assemblies, seminars/workshop, and orientation. It equally revealed that counselors do not use any follow-up strategy in monitoring students' behaviour after imparting vocational information to them. Implications of the findings were highlighted and recommendations were made.
\end{abstract}

Keywords: counseling, special education, behavioral issues

\section{Introduction}

Young people today are facing a complex and rapidly changing society. In spite of all efforts being put forth by schools and government agencies, an increasing large proportion of youths have and will continue to experience difficulty in making transition from the world of school to the world of work. It is in view of the above that the Federal Republic of Nigeria (2004) stated that the youth should be given adequate information on professions, occupations, as well as how to establish occupation on their own. Ifelunni and Agbaegbu (1996) opined that rapid changes in the economy in Nigeria have brought about the importance of manpower with great attention. As Nigeria economy continues to expand as a result of technological advancements, the nature of many jobs changes, and the need for occupation information and techniques of its provision to students become very important.

The students are faced with problems in seeking how to develop proper adjustment, and choosing career. They often look for help from different persons, such as the parents, peers, brothers and sisters, as well as teachers and counselors. What is more, the people these students approach for help are not competent to give valid and useable information to help them. In this regard, the counselor is the most competent person to give the students this assistance (Ishaku, 2005) and such information being provided makes available to students, knowledge of opportunities on educational, vocational, and personal social issues, so as to enable them to make

Omeje Joachim Chinweike, Ph.D., Department of Educational Foundations, University of Nigeria.

Eskay Michael, Ph.D., professor, Department of Educational Foundations, University of Nigeria.

Tenimu Sani, Ph.D., College of Education. 
authentic and satisfactory vocational plans. In providing such vocational information, the counselor uses media outlet, orientation, career day/week, field trip/excursion, individual counseling, group counseling, seminars, and assembling among other (Omeje, 2002).

To choose a career is an important decision that an individual has to make in life. As noted by Parson in Omeje (2002), there is no part of life where the need for guidance is more empathic than in transition from school to work. The choice of vocation, adequate preparation for it, and the attainment of efficiency and success can be enhanced through counseling process. The building of career is quite as difficult a problem as the building of a house. Yet, few ever sit down to plan a working career before a career choice.

The choice of career poses a lot of problem to the secondary school students, especially the senior secondary school students, in spite of the fact that the Federal Republic of Nigeria (2004) has in one of its purposes in vocational education as exposing students to career awareness by exploring usable options in the world of work. Young people must be prepared to cope with these changing trends by having the capacity to be resourceful, adaptable, and flexible amidst change and ambiguity. It is in this content of constant change that adolescents must make decisions regarding their life careers. Cooperative efforts of the school, home, and society are needed to help young people successfully make the transition from school to the world of work. What this implies is that career guidance is of utmost importance in the life of growing students.

Career guidance and counseling services as noted by Ochiagha (1995) are school provisions designed to assist individuals to move smoothly from school to work. Career guidance becomes a central component of a career education programme. Career education fosters realistic thinking because they enlarge the information one has about the world of occupation. It provides the youth basic knowledge and the opportunity to learn about the environment and themselves thus exposing them to the world of work.

In order for students to make realistic career choice, providing appropriate information by counselors as Agulana (1986) could be of great help for them to acquire competencies needed to enable them to make such choice. This indicates that career information as noted by Ochiagha (1995) is used to help the individual to understand the need to plan rather than to drift, broaden his/her outlook, and increase his/her appreciation of alternatives and their consequences, so that he/she may choose wisely, make sound decisions, and consciously control his behaviour. What this implies is that the behaviour being exhibited in work environment may have been influenced by vocational information received.

In spite of vocational information provided to aid the student in choice, it has been observed that there is poor attitude to work by Nigerian workers (Ochiagha, 1995). This poor attitude, which Nigeria workers manifest in work environment, is not in-born but results from some environmental factors. This makes monitoring of vocational behaviour of students imperative. Counselors in providing vocational information provide occupational orientation services and citizenship education/preparation in order to create some national consciousness and improve young peoples' attitude to work. Providing follow-up services to monitor students' utilization of vocational information services becomes imperative. Okeke (2003) opined that a follow-up service is designed to monitor the progress of students in their work places. Follow-up of students' activities is necessary since the result may bring about programme adjustment or improvement if out-right failure or unsatisfactory success has been detected.

Whether counselor who provides such vocational information that prepares the students for world of work goes to the extent of monitoring their work behaviour is yet to be determined. It is based on the above background that the researcher is interested in investigating counseling practices in monitoring vocational 
behaviour of students in tertiary institutions.

The questions, which the researcher posed to guide the study, are:

(1) What counseling approaches do counselors use in equipping students with vocational information for career choice?

(2) What follow-up strategies do counselors use in monitoring students' vocational performance/behaviour?

The study equally postulated two null hypotheses at $\mathrm{P} \alpha 0.05$ level of significant as:

(1) There is no significant difference between the mean rating of male and female counselors on counseling approaches counselors use in equipping students with vocational information form career choice;

(2) There is no significant difference between the mean ratings of male and female counselors on follow-up strategies counselors use in monitoring students' vocational performance/behaviour.

The result of this study is hoped to be of immense benefit to students who need proper guidance in their future career prospects. The information contained therein will help to reduce the high vocational guidance maladjustment. This will $x$-ray the approaches counselors use in providing vocational information. Also, the findings will determine if any relationships exist based on vocational information provided and work behaviour of which the level of follow-up exercise can be determine. This will help in modification.

\section{Methods}

The design for the study was a descriptive survey type. The study was conducted using counselors in Nsukka and Obollo Afor education zone of Enugu State. Nsukka educational zone is made up of three local government areas viz.: Nsukka, Igbo Etiti, and Uzo Nwani, while Obollo Afor education zone is equally made up of three local government areas as Igbo Eze South, Igbo Eze North, and Udenu. The population of practicing counselors in the two education zones is 115 . The population is made up of 72 females and 43 males. The entire population constituted the sample due to the smallness of the population. Therefore, no sampling technique was adopted.

The instrument used for data collection was a questionnaire. It is a 5-point scale type rating response. The face validity of the instrument was determined. The reliability of the instrument was determined in a preliminary survey of the instrument on a sample outside the target population. Cronbach Alpha was used to calculate the internal consistency of the instrument and reliability scores of 0.69 and 0.71 for the two clusters of the instrument were got. The researcher with the help of research assistants administered the questionnaire to the respondents. Mean score was used for analyzing the research questions while $t$-test statistics was used for testing the hypotheses.

\section{Results}

The analysis of data collected to determine approaches counselors use in equipping students with vocational information for career as indicated in Table 1 shows that all the identified approaches were rated above the criterion mean of 2.5. This shows that counselors use media outlet, individual counseling, group counseling, career day/week, field trip/excursion, assemblies, seminars/workshop, and orientation in equipping students with vocational information. The highest rated item in the table is career day/week with a mean of 3.70 while the least rated item is seminars/workshop with a mean of 2.55. Based on the analysis, a cluster mean of 3.23 which is above the 2.50 criterion mean was reached, it is established that all the items on the table are used 
by the counselor in equipping students with vocational information.

Table 1

Counseling Approaches Used by Counselors in Equipping Students With Vocational Information for Career Choice

\begin{tabular}{llll}
\hline S/N & Item description & Mean $(x)$ & Decision \\
\hline 1 & Media outlet & 2.90 & Accepted \\
2 & Individual counseling & 3.60 & Accepted \\
3 & Group counseling & 3.60 & Accepted \\
4 & Career day/week & 3.70 & Accepted \\
5 & Field trips/excursion & 3.65 & Accepted \\
6 & Assemblies & 3.00 & Accepted \\
7 & Seminars/workshop & 2.55 & Accepted \\
8 & Orientation exercise & 2.80 & Accepted \\
& Cluster mean $(x)$ & 3.23 & Accepted \\
\hline
\end{tabular}

Table 2

Follow-up Strategies Counselors Use in Monitoring Students' Vocational Performance/Behaviour

\begin{tabular}{llll}
\hline S/N & Item description & Mean $(x)$ & Decision \\
\hline 1 & $\begin{array}{l}\text { When students move to higher institution, the counselor having imparted vocational } \\
\text { information to them monitors their vocational performance or behaviour through } \\
\text { visitation. }\end{array}$ & 1.0 & Rejected \\
& $\begin{array}{l}\text { Counselor monitors their vocational performance or behaviour through administering } \\
\text { of questionnaire. }\end{array}$ & 1.01 & Rejected \\
3 & $\begin{array}{l}\text { Counselor monitors through requesting the institution to provide in writing and up to } \\
\text { date report on the students' vocational behaviour. }\end{array}$ & 1.05 & Rejected \\
4 & $\begin{array}{l}\text { Counselor uses peer mates of the students to monitor their vocational behaviour. } \\
\text { Cluster mean }(x)\end{array}$ & 2.30 & $\begin{array}{l}\text { Rejected } \\
\text { Rejected }\end{array}$ \\
\hline
\end{tabular}

From the analysis of Table 2, it could be observed that all the items of the instrument were rated negative and fell below the criterion mean of 2.50. The low mean scores ranged from 1.0 to 2.30. Based on the analysis where cluster mean of 1.34 was reached, it is established that counselors do not use any follow-up strategy in monitoring students' behaviour after imparting vocational information to them.

\section{Hypothesis 1}

The perceptions of male and female counselors do not differ significantly in their mean ratings of counseling approaches counselors use in equipping students with vocational information for career choice.

The data for testing the hypothesis are presented in Table 3.

Table 3

T-test Analysis of the Mean Rating of Male and Female Counselors on Counseling Approaches Counselors Use in Equipping Students With Vocational Information for Career Choice

\begin{tabular}{lllllllll}
\hline Group & No. & $X$ & $S D$ & $d f$ & $t$-cal & $t$-crit. & $\alpha$ level & Decision \\
\hline Male & 43 & 3.20 & 0.63 & 113 & -4.2 & 1.96 & 0.5 & Not significant \\
Female & 72 & 3.62 & 0.45 & & & & & \\
\hline
\end{tabular}

From Table 3, it can be observed that although the female counselors recorded higher mean score of 3.62 which is greater than the males mean score of 3.20, the difference in these mean scores is statistically not significant at $\mathrm{p} \alpha 0.05$. This is because the calculated $t$-value (-4.2) is less than the critical value (1.96). 
Therefore, the null hypothesis $\left(\mathrm{Ho}_{1}\right)$ is accepted, which implies that gender is not a factor in their perceptions of the approaches counselors use in equipping students with vocational information for career choice.

\section{Hypothesis 2}

The perceptions of male and female counselors do not differ significantly in their mean ratings of the follow-up strategies counselors use in monitoring students' vocational performance/behaviour.

The data for testing the hypothesis are presented in Table 4.

Test 4

T-test Analysis of the Mean Ratings of Male and Female Counselors on the Follow-up Strategies Counselors Use in Monitoring Students' Vocational Performance/Behaviour at $P \alpha 0.05$.

\begin{tabular}{lllllllll}
\hline Group & No. & $X$ & $S D$ & $d f$ & $t$-cal & $t$-crit. & $\alpha$ level & Decision \\
\hline Male & 43 & 1.12 & 0.78 & 113 & -0.57 & 1.96 & 0.05 & Not significant \\
Female & 72 & 1.20 & 0.71 & & & & & \\
\hline
\end{tabular}

From Table 4, it can be observed that although the male counselors recorded a lesser mean score of 1.12 compared to the female of 1.20 , the difference in these mean scores is statistically not significant at $\mathrm{p} \alpha 0.05$. This is because the calculated $t$-value $(-0.57)$ is less than the critical value (1.96). Therefore, the null hypothesis $\left(\mathrm{Ho}_{2}\right)$ is accepted, which implies that gender is not a factor in their perceptions of the follow-up strategies counselors use in monitoring vocational performance/behaviour of students.

\section{Discussion}

The research questions of the study focused on approaches counselors use in equipping students with vocational information for career choice and the follow-up strategies they use in monitoring students' vocational performance/behaviour. The results of the investigation show that counselors in equipping students with vocational information for career choice make use of approaches like media outlet, individual counseling, group counseling, career day/week, field trip/excursion, assemblies, seminars/workshop, and orientation exercise. This was based on attainment of cluster mean of 3.23, which is above the criterion mean of 2.50.

The present findings are in line with Omeje (2002) and Okeke (2003) who in discussing methods for disseminating vocational information to students highlighted the use of media outlet like listening to occupational programmes during career hours, the use of resource persons during career day/week, seminars, and orientation. They were also of the view that field trip, individual, and group counseling are of utmost importance in provision of such information.

The result also shows that although counselor provides vocational information for students which helps them in their career choice, they do not employ any follow-up strategy in monitoring their vocational performance or behaviour. This was based on attainment of cluster mean of 1.34, which was bellow the criterion means of 2.50. This contradicts the view of Okeke (2003), which opined that counselors in the discharge of their guidance service embark on follow-up service as a way of monitoring the progress of students in their work places.

The analysis of the significant difference between the perceptions of male counselors and female counselors as it concerns the approaches counselors use in equipping students with vocational information for career choice and the follow-up strategies they use to monitor students vocational performance or behaviour at p $\alpha 0.05$ shows that there mean scores are not statistically significant. 
In hypothesis $1, t$-calculated value (-4.2) did not exceed the $t$-critical (1.96) at $\mathrm{p} \alpha 0.05$ making the researcher to accept null hypothesis $1\left(\mathrm{Ho}_{1}\right)$. Also in hypothesis 2 , the $t$-calculated value $(-0.57)$ did not exceed that $t$-critical value (1.96) at $\mathrm{p} \alpha 0.05$ making the researcher to accept the null hypothesis $2\left(\mathrm{Ho}_{2}\right)$. This is an indication that gender is not an issue in their perceptions of the items.

\section{Conclusions and Recommendations}

Vocational information is central in school guidance and counseling programme. Students need vocational information, which aims at assisting individuals to acquire and utilize knowledge, skills, and attitudes that will make work meaningful, productive, and satisfying in the world of work. School guidance counselors are entrusted with the provision of all this important information service to young growing students. It is quite unfortunate that these counselors do not have ways of following up their clients whom they have equipped with basic vocational information for realistic career choice.

The implication of the findings of this study is that because there is no follow-up provided by counselors, the students are bound to drift into occupations of their choice as a result of fantasy and not through realistic backing.

The present study was limited by the fact that the researcher used only as a focus students leaving those in actual world of work. This may have affected the perceptions of the counselors in responding to the items of the instrument. Furthermore, the result could have been different if ascertaining the extent of students' utilization of vocational information services was investigated alongside the present study. The researcher then suggests such area for further research. Equally, the study recommends counselors' utilization of follow-up services in provision of vocational information services for students.

\section{References}

Agulana, G. S. (1986). The effect of career conference on the career choice competencies. (Unpublished master's thesis, University of Nigeria)

Federal Republic of Nigeria. (2004). National policy on education (4th ed.). Lagos: NERDC.

Ifelunni, C. S. I., \& Agbaegbu, C. N. (1996). Guidance, counseling and special education. Onitsha: Leatina (Nig.) Ltd..

Ishaku, A. A. (2005). A survey of problems encountered by counselors in rendering information services in Wukari education zone. (Unpublished B.Ed. Project, University of Nigeria)

Ochiagha, C. C. (1995). Theory and practices of career development. Enugu: SNAAP Press Ltd..

Okeke, B. A. (2003). Principles of guidance and counseling: An outline for beginners (3rd ed.). Enugu: SNAAP Press Ltd..

Omeje, J. C. (2002). Educational and occupational information in counseling: A fundamental approach. Nsukka: Chidube Educational Books. 